\title{
The efficiency of rehabilitation programs in the case of unoperated lumbar disc herniations
}

\author{
Mihaela VARGA ${ }^{1}$, Ana Maria VUTAN²
}

\begin{abstract}
Introduction: More and more young people with low back pain address family doctors or orthopaedists, being subsequently directed to the medical rehabilitation centres. Recent studies have shown that the medication only, prescribed in these cases, is not sufficient for the complete reintegration of these people into the workplace and into society. Physical exercises play an important role in the rehabilitation of these subjects. Aim: We conducted this study starting from the hypothesis that regular exercise can reduce pain and improve the well-being of patients diagnosed with lumbar disc herniation. Methods: The study was conducted at the "Politehnica" University of Timisoara within the Department of Physical Education and Sports, between September and November 2019. Ten subjects diagnosed (both clinically and by imaging) with lumbar disc herniation were included in the study. All patients followed an exercise program 3 times a week, for 90 days. As evaluation methods we used: the subjective pain evaluation scale (VAS scale) and the health assessment questionnaire (HAQ).

Results: All the parameters followed in this study were improved following the application of the physical exercise program (muscle stretching, toning of the back and abdomen muscles, and as a result of the correct implementation of the notions of ergonomics at work and at home). In conclusion, we consider it is necessary to implement a protocol of exercises performed regularly for a long period in the case of patients with lumbar pain secondary to disc herniation.
\end{abstract}

Key words: lumbar disc herniation, exercise, pain relief.

\section{Rezumat}

Introducere: Tot mai multe persoane tinere cu dureri lombare se adresează medicilor de familie sau ortopezilor ulterior fiind directionate spre cabinetele de recuperare medicală. Studiile recente au aratat că doar medicatia prescrisă în aceste cazuri nu este suficientă pentru reintegrarea completă a acestor persoane la locul de munca și în societate. Exercițiile fizice ocupă un loc important în reabilitarea acesor subiecți. Scopul lucrării: Am plecat în acest studiu de la ipoteza că exercițiile fizice efectuate regulat pot reduce durerea și pot îmbunătăți starea de bine a pacienților diagnosticați cu hernie de disc lombară. Metode: Studiul a fost realizat la Universitatea „Politehnica” din Timișoara, în cadrul Departamentului de Educație Fizică și Sport, în perioada septembrie-noiembrie 2019. Au fost incluși ăn studiu zece subiecți diagnosticați (atât clinic, cât și imagistic) cu hernie de disc lombară. Toți pacienții au urmat un program de exerciții de 3 ori pe săptămână, timp de 90 de zile. Ca metode de evaluare am folosit: scala subiectivă de evaluare a durerii (scala VAS) și chestionarul de evaluare a sănătății (HAQ).

Rezultate: Toți parametrii urmăriți în acest studiu s-au îmbunătățit în urma aplicării programului de exerciții fizice (stretching muscular, tonifierea musculaturii spatelui și abdomenului și implementarea corectă a noțiunilor de ergonomie la locul de muncă și la domiciliu). În concluzie considerăm necesară implementarea unui protocol de exerciții efectuate regulat pe o perioadă îndelungată în cazul paciențior cu durere lombară secundară herniei de disc.

Cuvinte cheie: hernie de disc lombară, exerciții fizice, reducerea durerii,

\footnotetext{
${ }^{1}$ Assistant Professor, PhD, Politehnica University of Timisoara, Department of Physical Education and Sports, Romania

2 Physiotherapist, Assistant Professor, PhD student, West University of Timișoara, Physical Education and Sports Faculty, e-mail:

ana.vutan@e-uvt.ro
} 


\section{Introduction}

Disc herniation is a degenerative disease with a high incidence, plurilateral etiology and extremely varied clinical expression. Neurological sequelae with definitive physical disability are a common complication of this disease. Over $80 \%$ of the population endures at least one episode of low back pain throughout their lives [1].

Lumbar disc herniation (HDL) is a complex medical problem, with great social and economic impact. It occurs with increased frequency in economically developed and developing countries, and it involves many etiological factors, such as biological, psychological and social factors, which largely influence the therapeutic effects [2].

Every year, a large part of the population loses their ability to work because of back pain and its complications. Considering the long persistence of the symptoms and the remitting character of the pathology, the load on the health systems is a considerable one.

In the US, the annual incidence of low back pain is estimated at $5 \%$, associated with a prevalence of $60 \%$ to $90 \%$. For example, in the US alone, the annual expenses provided by medical insurance companies reach several billion dollars. In international practice, surgical treatment occupies the leading position in the treatment of lumbar disc herniation $[1,3]$.

The frequency of hospitalizations due to lumbar disc herniation has been steadily increasing, and, in the last decade, this figure has increased almost 3 times. Many patients with disc herniation have low back pain and prolonged pain in the lower limb (sciatica). In the Mini-Finland Health survey, $5.1 \%$ of the participants aged between 30 and 64 years old, were diagnosed with sciatica. In the health sector (in Central Finland) 90 operations are reported per 100,000 inhabitants. In the Netherlands, with a population of about 16 million inhabitants, 10,000 to 11,000 operations are performed each year [4].

Apart from the fact that low back pain creates substantial morbidity, its treatment is very expensive. Between $\$ 33$ billion and $\$ 55$ billion are spent each year on direct medical costs for the treatment of low back pain in the US $[1,2,3]$.

\section{Aim}

In this paper we aim to demonstrate that performing a rehabilitation program, in HDL patients, it can contribute to relieve the pain and improve spine mobility, thus offering a better quality of life for these patients.

\section{Material and methods}

The study was conducted at the "Politehnica" University of Timisoara within the Department of Physical Education and Sports, between September and November 2019. Ten subjects diagnosed (both clinically and by imaging) with lumbar disc herniation were included in the study. The treatment for each patient lasted 90 days.

In order to select the persons to take part in the study, the following exclusion criteria were set:

- the age of the persons in the study between 25 and 65 years;

- all patients were diagnosed with lumbar disc herniation;

- none of the persons participating in the study underwent surgery of the spine;

- the diagnosis is at least 3 years old;

- the patients do not present any other conditions that could constitute contraindications for the practice of physical activities.

A written informed consent for participation was obtained from each subject prior to enrolment. All subjects completed a comprehensive screening medical evaluation, including a medical history and a physical examination.

Additionally, patients were followed up for 3 months, two visits were made, one for the initial evaluation and another for the final evaluation of the experimental protocol.

As evaluation methods we used:

- the VAS scale, the subjective pain evaluation scale;

- the health assessment questionnaire, HAQ (Health Assessment Questionnaire).

The VAS scale is a method of assessing the intensity of pain used in various pathologies in adults. It is a scale from 0 to 10 , each patient being able to selfevaluate in terms of pain intensity ( 0 - no pain, 10 highest pain that the patient can feel).

The quality of life and functional status were assessed through the Health Assessment Questionnaire (HAQ). In this study we used the abbreviated variant of HAQ. The disability index (disability) assesses eight areas: dressing and selfcare, lifting, feeding, moving (walking), hygiene, bending (to reach an object), grasping 
(prehension) and daily activities. For each functional compartment there is at least one relevant question and each answer is scored from 0 to 3 . The disability index is calculated using the eight functional parameters, performing either their arithmetic mean or the sum of the eight.

After the initial evaluation, the subjects performed an exercise program 3 times a week, for 90 days (for 3 months).

The objectives of the physical exercise program were:

- pain control;

- improvement of joint mobility and stability;

- reharmonization of the physiological curves of the spine;

- toning the muscles of the spine.

All patients followed the same exercise program. The exercises included: - stretching exercises for the back muscles of the spine and also iliopsoas and hamstring muscles ( 5 repetitions of 20 -sec hold and 20 -sec of rest), - strengthening exercises for the back, abdominal, gluteal and iliopsoas muscles (10 repetitions with a 5-sec hold). Finally, all participants received ergonomic guidelines relevant to back problems, such as standing and sitting postures, reaching, kneeling, twisting, lifting, pushing and pulling, all movements used in everyday activities.

All assessments were performed at the beginning of the study and again, 3 months after the initiation of this intervention. The statistical analysis was performed using the Statistical Package for the Social Sciences (SPSS version 20). Student's t test for paired data (two tailed) was used for the comparison of the mean values in the group of patients. A Levene's test was done before, in order to assess the equality of variances. Values of $\mathrm{p}<0.05$ were considered significant.

\section{Results}

A total of 10 patients fulfilled the inclusion criteria and completed the study. The general characteristics of the patients are presented in Table I.

The age of the studied patients was between 25 and 48 years (mean age 36.7 years). We noted that the disease is more common in young people, male, over 30 years old. In our study only 4 patients perform hard physical activity, the rest of the subjects performing a light and moderate physical activity
(Table I). Most patients had chronic low back pain (70\%).

Table I. General characteristics of the study group

\begin{tabular}{ll}
\hline Parameter & Value \\
\hline Age (years) (mean) & 36.7 \\
\hline Sex (M/F) & $6 / 4$ \\
\hline Social environment (U) & $6 / 4$ \\
\hline $\begin{array}{l}\text { Type of the pain } \\
\text { - chronic } \\
\text { - } \quad \text { subacute }\end{array}$ & $7(70 \%)$ \\
\hline Physical activity (\%): & $3(30 \%)$ \\
- hard & \\
- moderate & $4(40 \%)$ \\
- light & $1(10 \%)$ \\
\hline
\end{tabular}

Significant reduction in pain intensity was observed after 3 months of exercise program $(p=0.004)$ (Table II).

Table II. The average intensity values of the initial and final pain

\begin{tabular}{lccc} 
& $\begin{array}{c}\text { Arithmetic } \\
\text { mean }\end{array}$ & $\begin{array}{c}\text { Standard } \\
\text { deviation }\end{array}$ & $\mathrm{P}$ \\
\cline { 1 - 3 } Initial VAS & 53 & 12.51 & $\mathbf{0 . 0 0 4}$ \\
\cline { 1 - 3 } Final VAS & 29.5 & 11.65 & \\
\hline
\end{tabular}

Another particularly important parameter that we evaluated in this study was the functional status of the patients (HAQ questionnaire) (Tables III, IV). We observed that, initially, compared to a general average of 17.6 points, 5 patients have general scores below the average, and the rest of the patients are above average (Table III). The worst situation is presented by patients S.M (10 p.), M.L (11 p.) and R.S (12 p.). On a scale from 0 to 3 , for the eight aspects of health status, 2.2 points were registered (on average). From the table above we can see that general values below the average of $2.2 \%$ have "moving/walking" activities (1.9\%) and "daily routine" activities (1.5\%). Patients scored the best score for "grasping" activities.

The results obtained after the 3 months of treatment are presented in the table IV. 
Table III. HAQ initial

\begin{tabular}{|c|c|c|c|c|c|c|c|c|c|}
\hline 苛 & 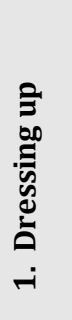 & 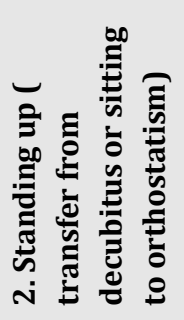 & 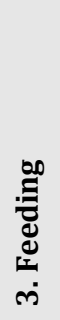 & 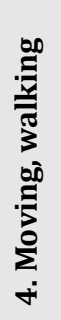 & 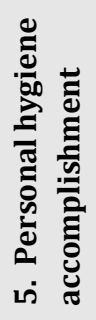 & 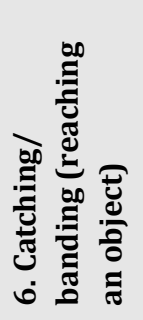 & 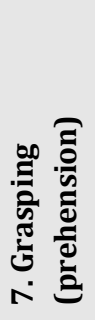 & 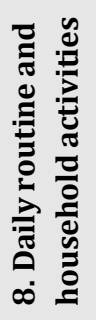 & Total \\
\hline B.A & 2 & 3 & 3 & 3 & 3 & 3 & 3 & 2 & 22 \\
\hline I.S & 3 & 3 & 3 & 2 & 3 & 3 & 3 & 2 & 22 \\
\hline S.M & 1 & 1 & 1 & 1 & 1 & 1 & 3 & 1 & 10 \\
\hline P.S & 3 & 1 & 2 & 2 & 2 & 3 & 3 & 1 & 17 \\
\hline R.S & 2 & 1 & 2 & 2 & 1 & 1 & 2 & 1 & 12 \\
\hline R.N & 3 & 3 & 3 & 3 & 3 & 3 & 3 & 2 & 23 \\
\hline C.C & 3 & 3 & 3 & 2 & 3 & 3 & 3 & 2 & 22 \\
\hline M.L & 1 & 1 & 2 & 1 & 1 & 1 & 3 & 1 & 11 \\
\hline V.F & 2 & 2 & 2 & 1 & 2 & 2 & 3 & 1 & 15 \\
\hline L.M & 3 & 3 & 3 & 2 & 3 & 3 & 3 & 2 & 22 \\
\hline Average & 2.3 & 2.1 & 2.4 & 1.9 & 2.2 & 2.3 & 2.9 & 1.5 & 17.6 \\
\hline
\end{tabular}

Table IV. HAQ final

\begin{tabular}{|c|c|c|c|c|c|c|c|c|c|}
\hline 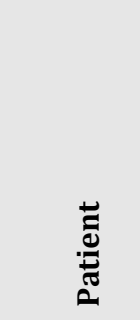 & 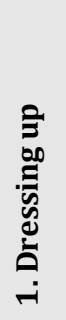 & 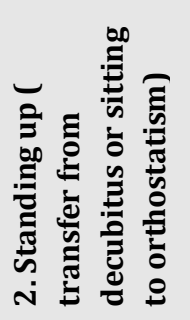 & 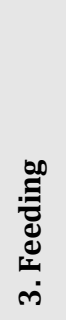 & 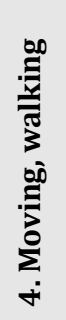 & 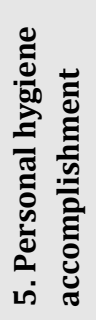 & 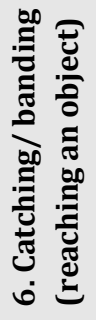 & 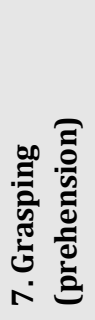 & 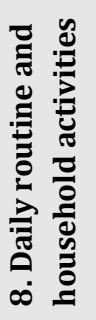 & Total \\
\hline B.A & 3 & 3 & 3 & 3 & 3 & 3 & 3 & 3 & 24 \\
\hline I.S & 3 & 3 & 3 & 3 & 3 & 3 & 3 & 3 & 24 \\
\hline S.M & 2 & 2 & 2 & 2 & 2 & 2 & 3 & 2 & 17 \\
\hline P.S & 3 & 3 & 3 & 3 & 3 & 3 & 3 & 2 & 23 \\
\hline R.S & 2 & 2 & 2 & 2 & 2 & 2 & 2 & 2 & 17 \\
\hline R.N & 3 & 3 & 3 & 3 & 3 & 3 & 3 & 3 & 24 \\
\hline C.C & 3 & 3 & 3 & 3 & 3 & 3 & 3 & 3 & 24 \\
\hline M.L & 2 & 2 & 2 & 2 & 2 & 2 & 3 & 2 & 17 \\
\hline V.F & 3 & 3 & 3 & 2 & 3 & 3 & 3 & 2 & 22 \\
\hline L.M & 3 & 3 & 3 & 3 & 3 & 3 & 3 & 3 & 24 \\
\hline Average & 2.7 & 2.7 & 2.7 & 2.6 & 2.7 & 2.7 & 3 & 2.5 & 21.6 \\
\hline
\end{tabular}


Table V. Initial and final status evaluation

\begin{tabular}{lccc} 
& $\begin{array}{c}\text { Arithmetic } \\
\text { mean }\end{array}$ & $\begin{array}{c}\text { Standard } \\
\text { deviation }\end{array}$ & $\mathrm{P}$ \\
\cline { 1 - 3 } $\begin{array}{l}\text { HAQ } \\
\text { initial }\end{array}$ & 17.6 & 5.23 & $\mathbf{0 . 0 5}$ \\
\cline { 1 - 2 } HAQ final & 21.6 & 3.23 & $\mathbf{4}$ \\
\hline
\end{tabular}

We can say that, compared to a general average of 21.6 points, 3 patients have overall scores below the average, and the rest of the patients are above average. Following the application of the physical exercise program, on average, all patients registered a significant improvement of the functional status ( $\mathrm{p}$ $=0.054$ ) (Table V).

On a scale from 0 to 3 , for the eight aspects of the health status, there was an average of 2.7 points. Only for the "daily routine" activities the values were below the average (2.7p).

From the data presented above, we can observe an improvement of the 8 items in the HAQ questionnaire, which indicates an improvement in the patients' quality of life. Significant improvements were recorded in activities related to "walking" (36\%) and those related to "daily routine" activities (66\%).

Therefore, following the results presented above, all subjects were able to reduce pain, improve functional status, and ultimately improve quality of life.

\section{Discussions}

Herniated lumbar disc is a displacement of disc material (nucleus pulposus or annulus fibrosis) beyond the intervertebral disc space. It is commonly found in young subjects, aged between 30 and 50 years, predominantly males. There is little evidence to suggest that drug treatments are effective in treating herniated disc.

In our study we started from the premise that the application of a physical exercise program, performed 3 times a week, will lead to pain relief, improvement of functional capacity and quality of life in patients with unoperated lumbar disc herniation.

According to the results of this study, this hypothesis was confirmed, namely, we found a significant decrease in pain intensity $(p=0.004)$ and $a$ significant improvement in the functional status of the patients studied $(\mathrm{p}=0.054)$.

We noticed an improvement of the 8 items in the HAQ questionnaire, which indicates an improvement in the patients' quality of life. Significant improvements were recorded in activities related to "walking" (36\%) and those related to "daily routine" (66\%).

Similarly to our study, Bhadauria E.A et al. concluded that physical exercises (lumbar stabilization, dynamic strengthening and Pilates) are effective in reducing pain and improving the range of motion, core strength and function [5].

In addition, several studies have reported that programmes with stretching and strength-training exercises are most effective in reducing pain severity and improving functional outcomes $[6,7,8]$.

\section{Conclusions}

Physical exercises are often prescribed for patients with low back pain and other spinal problems. Patients suffering from low back pain are often referred for physical therapy as an initial conservative treatment option before considering surgical treatments.

The goals of physical exercises are to decrease pain, increase function and prevent future back problems.

\section{References}

1. Deyo R.A., Weinstein J.N. (2001). Low back pain, New England Journal of Medicine, 344, 363-370.

2. Saal J.A. (1996). Natural history and nonoperative treatment of lumbar disc herniation, Spine, 21(24 Suppl):2S-9S.

3. Walker B.F. (2000). The prevalence of low back pain: a systematic review of the literature from 1966 to 1998, Journal of Spinal Disorders, 13, 205-217.

4. Dalstra J.A.A., Kunst A.E., Borrell E. et al. (2005). Socioeconomic differences in the prevalence of common chronic disease: an overview of eight European countries, International Journal of Epidemiology, 34, 316-326.

5. Bhadauria E.A. (2017). Comparative effectiveness of lumbar stabilization, dynamic strengthening, and Pilates on chronic low back pain: randomized clinical trial, Journal of Exercise Rehabilitation, 13(4),477-485. 
6. Hayden J.A., Van Tulder M.W., Tomlison G. (2005). Systematic review: strategies for using exercise therapy to improve outcomes in chronic low back pain, Annales of Internal Medicine, 142, 765-75.

7. Kankaanpaa M., Taimela S., Airaksinen 0., et al (2004). The efficacy of active rehabilitation in chronic low back pain, Spine, 24, 1034-42.

8. Taylor N.F., Dodd K.J., Shields N., Bruder A. (2007) Therapeutic exercise in physioyherapy practice is beneficial: a summary of systematic reviews 2002-2005, Australian Journal of Physiotherapy, 53, 7-16. 